\title{
砂河川における付着藻類の 空間分布に関する研究 SPATIAL DISTRIBUTION OF ATTACHED ALGAE IN A SAND RIVER
}

\author{
戸田祐嗣 1 多田隈由紀 ${ }^{2} \cdot$ 辻本哲郎 3 \\ Yuji TODA, Yuki TADAKUMA and Tetsuro TSUJIMOTO \\ 1正会員 博 (工) 名古屋大学大学院助教授 工学研究科 (†464-8603 名古屋市千種区不老町1) \\ 2 名古屋大学大学院 工学研究科 (T464-8603 名古屋市千種区不老町1) \\ 3 フェロー 工博 名古屋大学大学院教授 工学研究科 (†464-8603 名古屋市千種区不老町1)
}

\begin{abstract}
While the growth of attached algae is usually observed on gravel bed river, the large growth of them is sometimes seen even in sand rivers if river discharge is considerably small enough to provide the favorable habitat for attached algae. In the present study, field observations and numerical simulations were performed to know the growth of attached algae in a sand river. In the field observations, the growth of attached algae on fixed sand bed was measured weekly to identify the physiological characteristics of attached algae on sand surface. An integrated numerical simulation model is presented to describe the growth of attached algae on sand river, and the model can roughly predict the spatial distribution of attached algae. A series of numerical tests of growth of attached algae was performed under the various discharge conditions, and the effects of river discharge on growth of attached algae were discussed.
\end{abstract}

Key Words : attached algae, sand river, growth model, mobility of bed material, river discharge

\section{1. 序論}

河川水中において付着藻類は主たる一次生産者で あり，光合成活動を通して有機物を生産し，水生生 物のエネルギー源として河川生態系を根幹から支え ている.このような役割を果たす藻類の動態を明ら かにすることは, 河川生態系の中での物質・エネル ギーの流れを把握することに繋がる.

一般に付着藻類の生育のためには, 河床まで日射 が到達し, 藻類の生息場である河床材料が流れの中 で安定している必要がある。そのために, 浅い碟河 川の河床においては, 通常, 付着藻類の繁茂が確認 され, 礫河川の藻類繁茂特性に関する研究が数多く 行われてきた。しかし流域に農業地帯を有するなど， 利水による取水の大きい砂河川においては，本来付 着藻類の発達に適さない砂床上でも付着藻類の繁茂 が確認される1). 原因は，取水による河川の流量の 減少, 水深の低下, 河床材料の移動頻度の減少が考 えられる. 本研究では利水による取水の大きい砂河 川である矢作川において, 現地観測を行ない付着藻 類の分布状況を把握すると共に，流れの影響を考慮 した藻類の増殖解析手法を提案し, 砂面上の付着藻
類繁茂特性を明らかにすることを目的とする。また， 開発した計算手法を用いて河川流量を変化させた場 合の計算を行い，人為的な河川流量の操作が砂河川 の藻類一次生産に与える影響を明らかにする.

\section{2. 現地調査}

\section{(1) 観測地 - 観測期間概要}

本研究の対象地は, 愛知県を流れる矢作川の河口

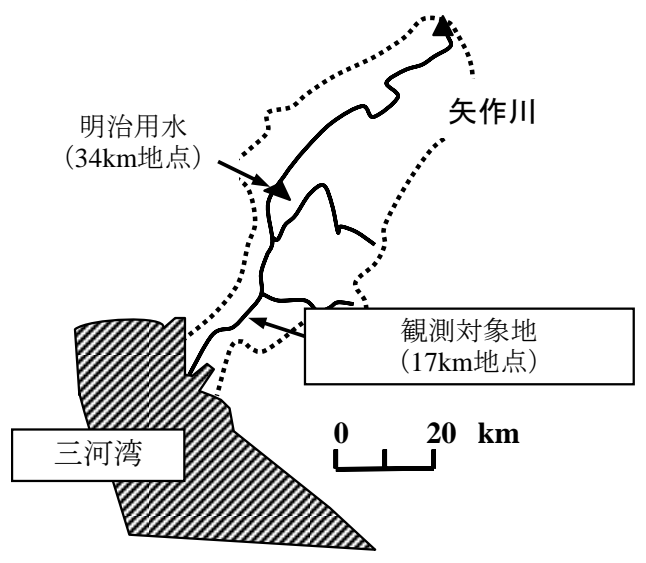

図-1 観測対象地 


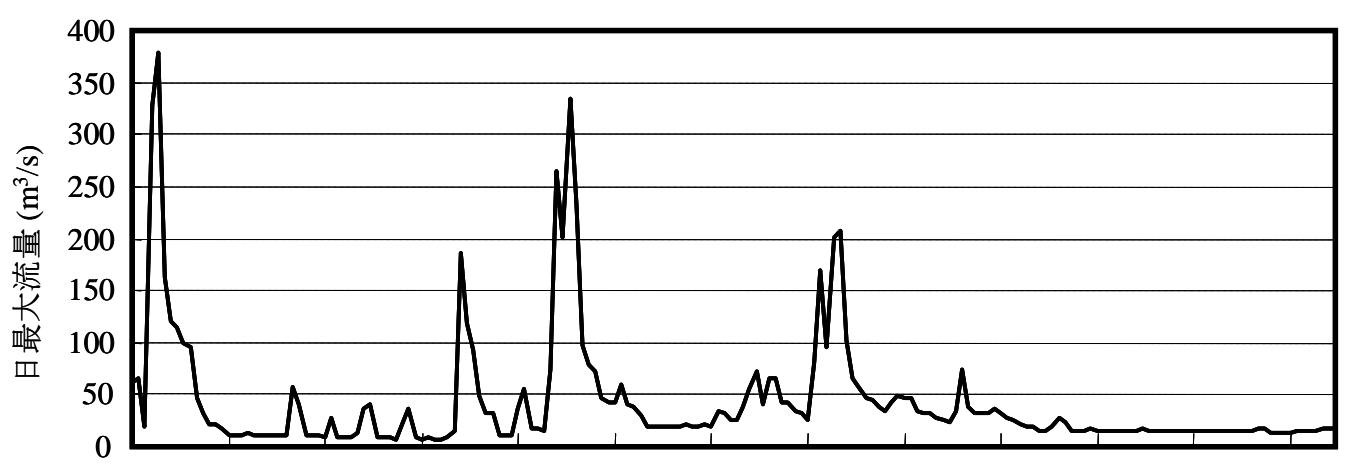

Jul.1 Jul.16 Jul.31 Aug.15Aug.30 Sep.14 Sep.29Oct.14 Oct.29 Nov.13Nov.28Dec.13 Dec.28

図-2 観測期間の河川流量

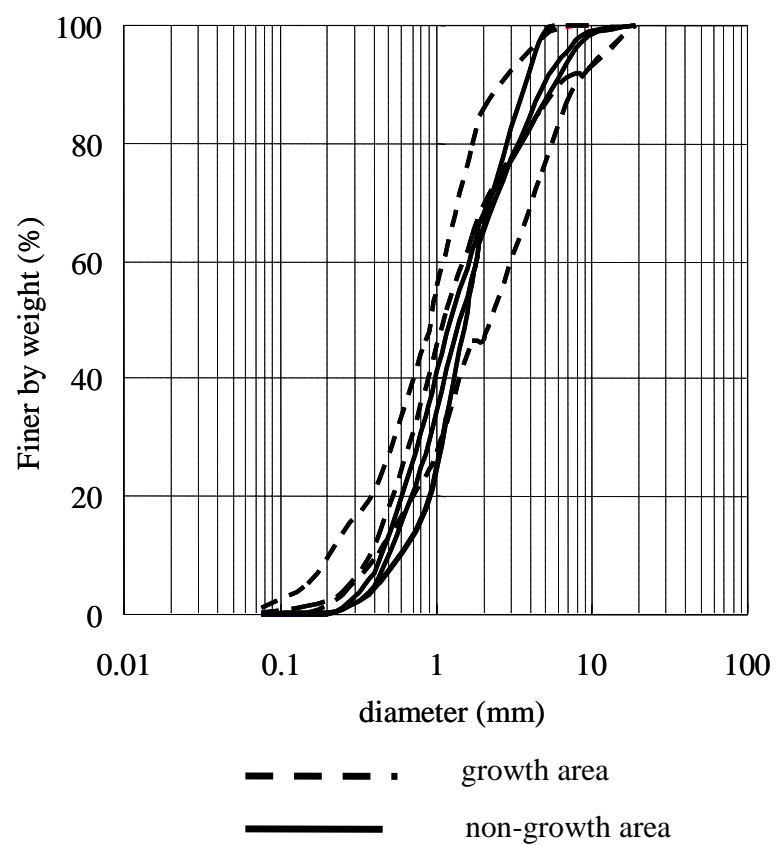

図-3 観測対象域の河床材料

より約 $17 \mathrm{~km}$ 地点付近である（図-1）。矢作川下流 域には多くの農業地域があり, 灌溉期にはこれらの 農地一の水を供給するため, 河口より約 $34.6 \mathrm{~km} に$ 位 置する明治用水から常時 $30 \mathrm{~m}^{3} / \mathrm{s}$ の河川水を取水して いる. この取水により, 矢作川下流域では平水時の 河川流量が低下しており, 概ね $20 \sim 30 \mathrm{~m}^{3} / \mathrm{s}$ の範囲で 変動している. 図-2に2005年7月から同12月までの 6ヶ月間の日最大流量の変化を示す. 観測対象域の 平水時の流量はおよそ $23 \mathrm{~m}^{3} / \mathrm{s}$ である。観測期前半の 夏季から10月後半にかけては台風や秋雨前線の通過 により流量が増加しているが，観測期後半の11月以 降については, 流量の変動が小さく, 安定した流況 がつづいていたことが分かる.

\section{(2) 観測の概要}

観測は2005年7月から同12月の間に月一度の頻度 で行なった。現地観測では藻類の空間分布を把握す るため, 現地踏查時に目視により判断される河床付 着藻類の植被エリアの境界線をGPSによって記録し
た。また，上記の期間中の付着藻類群の生理特性を 把握するために，河床に藻類付着用プレートを設置 し, 藻類の増殖実験を行った。まず対象リーチ河道 内の河床材料を持ち帰り乾燥させ，ふるい分け試験 により粒度分布を求めた。その結果より, 試料の大 部分を占めるのは粒径が $0.425 \mathrm{~mm} \sim 4.75 \mathrm{~mm}$ のの であった。そこで粒径が $0.425 \mathrm{~mm} \sim 4.75 \mathrm{~mm}$ の混合 試料をボンドで貼り付けた藻類付着用プレートを大 量に作成した。一つのプレートの大きさは $7 \mathrm{~cm} \times$ 7cmである。これらのプレートをやぐらに固定し, 河川水中に設置し，第1回7/16 9/21，第2回9/15～ $11 / 10$, 第3回 10/31 12/12の期間で増殖実験を行 なった。やぐらの設置高さについては，低流量時に 冠出せず, 高流量時（増水時）に土砂に埋没しない よう, 河床面から $10 \sim 20 \mathrm{~cm}$ 程度上方に藻類付着用 プレートの面が来るように設置した。それぞれの回 について，2週間に1度程の頻度で3枚のプレートを 取り出し, プレート表面に付着した藻類を歯ブラシ で剥がし取った。 SCOR-UNESCO法 ${ }^{2}$ にて，採集し た試料のクロロフィルa量（Chl.a）を測定した.

\section{(3) 観測結果}

a) 付着藻類の繁茂域と非繁茂域の粒度分布

付着藻類の繁茂域および非繁茂域の河床材料を 採取しふるい分け試験を行い, それぞれ平均粒径を 求めた (図-3)。両者の間には特に系統的な差異は見 られなかった。このことから本観測対象地において は，藻類の繁茂域・非繁茂域での粒径は同程度であ り，粒径の空間的な変化は小さいものと判断される. b) Chl.a量の変化

固定砂面上のChl.a量の時間変化を図-4に示す. これらのグラフに, 後述する式(1)で示すロジス ティック方程式をフィッティングし, 藻類生長のパ ラメータである比増殖速度と環境容量を求めた結果 を表-1に示寸。本増殖実験では，夏季（第1回目） の実験時に藻類量のばらつきが大きい。また，ロジ スティック曲線を用いて藻類の増殖特性を検討した 既往の研究3)では, 8〜10回程度以上の藻類量の計測 結果からパラメータを同定しているのに対して, 本 研究では，一つの実験期間中に3〜4回ほどしか藻類 


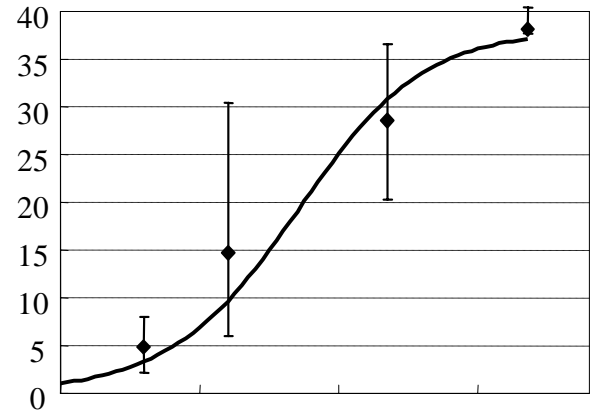

$\begin{array}{llll}\text { Jul. } 16 & \text { Aug. } 5 & \text { Aug. } 25 & \text { Sep. } 14\end{array}$

(a) Summer in 2005

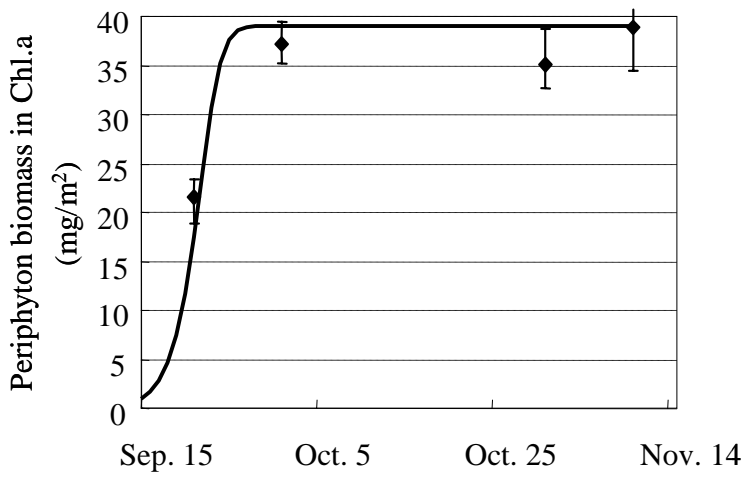

(b) Summer to Autumn in 2005

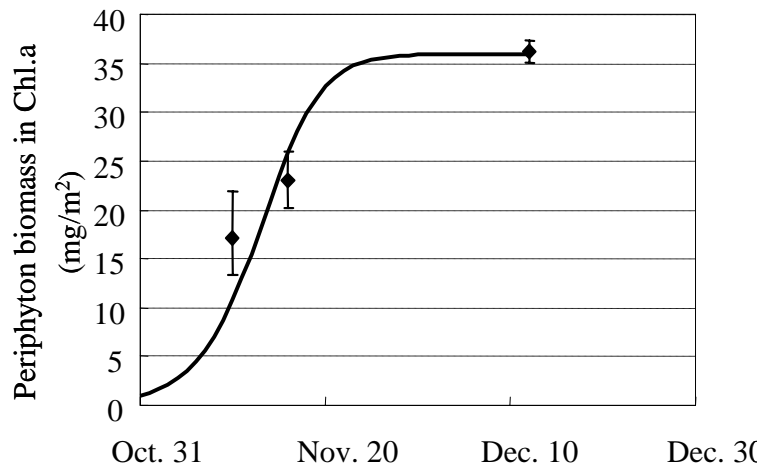

(c) Autumn to Winter in 2005

図-4 固定砂面上での藻類の増殖

量の計測を行えなかった。 そのため, 比増殖速度や 環境容量の值そのものを詳細に議論するには, 精度 面での検証が不十分であり, 更なるデータの蓄積が 必要であるが, 大局的には以下のような特徵が見ら れた。

砂面上の藻類量については，観測期間によって差 は見られるが，3〜8週間で35〜 40 $\mathrm{mg} / \mathrm{m}^{2}$ (chl.a量) まで到達することが観察できる。これらの藻類量は, 磎床河川の河床碩表面で観測される生物量（例えば 多摩川中流域㗂床区間での藻類量で $20 \sim 50 \mathrm{mg} / \mathrm{m}^{2}$ (chl.a量） ${ }^{4)}$ ) に匹敵し, 砂の移動がなければ砂河 床面上においても礫河川と同程度の付着藻類の繁茂 が生じることが分る.

増殖速度について，3回の実験結果を比較すると，
表-1 ロジスティック曲線のフィッティングにより得られた 藻類増殖に関するパラメータ

\begin{tabular}{|c|c|c|}
\hline & $\begin{array}{c}\mu \\
\left(\text { day }^{-1}\right)\end{array}$ & $\begin{array}{c}K \\
\left(\mathrm{mg} / \mathrm{m}^{2}\right)\end{array}$ \\
\hline Jul. to Aug. & 0.11 & 38 \\
\hline Sep. to Nov. & 0.70 & 39 \\
\hline Nov. to Dec. & 0.33 & 36 \\
\hline
\end{tabular}

1回目より2，3回目の実験で増殖率が大きいことが 分かる. 特に2回目においては増殖速度が極めて大 きい. 増殖速度の值そのものについては, 前述の通 り, データ数やばらつきの問題から現時点では詳細 な議論が出来る精度ではないが，少なくとも，第2 回目の実験期間にはプレート設置から2週間ほどで $37 \mathrm{mg} / \mathrm{m}^{2}$ 程度の藻類量まで増殖が進み, 最も増殖活 性が高かったものと判断される.

第1回目の実験時期に相当する 7，8月は平均水温 がほかの月に比べて高く, 日射量も大きい. 通常, 藻類の生長は日射量の増大とともに大きくなるが, 夏季の晴天時のような強い日射の下では光合成速度 が低下寸る（強光阻害）ことが知られている. 強光 阻害を生じさせる照度は, 藻類種, 水温, 栄養塩濃 度に依存するが，200〜300W/ $\mathrm{m}^{2}$ を超える強光下で 報告されている事例が多い5). 観測対象地では平水 流量時の水深は $1 \mathrm{~m}$ 以下で河川水の濁度も小さい. 河川水の吸光係数の計測は行っていないが, 仮に水 深 $1 \mathrm{~m}$ 河川に対して, 純水の吸光係数 0.28 用いて 河床への日射量を算出すると，水中に透過した日射 の75\%程度は河床一到達する。夏季の日中平均日射 量は300 400W/ $/ \mathrm{m}^{2}$ に到達するため ${ }^{6)}$, 第1回目の実 験期間時の日中には，河床へ $220 \sim 300 \mathrm{~W} / \mathrm{m}^{2}$ 程度の 日射が到達していたものと推察され, その結果とし て, 第1回目の実験期には強光阻害によって増殖が 低下した可能性が示唆される. その後, 秋季の第2 回目実験期に入り水温・日射が少し低下寸ると，増 殖率が増加しているが，冬季の第3回目実験期にな ると, 光量, 水温の低下により活性が小さくなった ものと思われる.

なお，藻類の増殖実験期間中には $100 \mathrm{~m}^{3} / \mathrm{s}$ を超え る出水が3回生じており, 流れの掃流力の変化に よって付着藻類の剥離が生じた可能性がある。しか し, 現地観測では出水の直前・直後の藻類量を計測 できなかったため，その効果を抽出するには至って いない. 今後の課題である.

\section{3. 数值解析}

\section{（1）数值解析モデルの概要}

現地観測の結果, 砂河床表面においても, 砂の移 動が生じなければ藻類が繁茂することが確認された。 


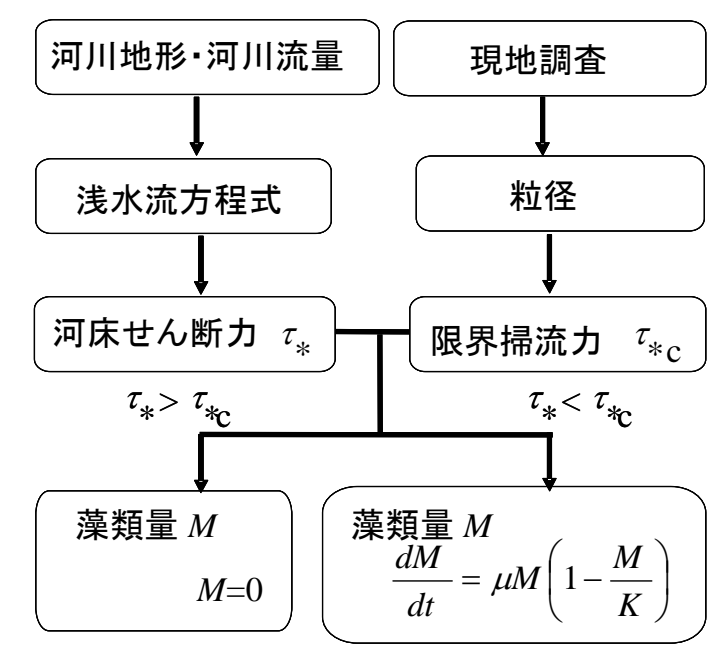

図-5 本解析のフローチャート

このことから，河床の砂が移動しない場所・期間を 流れ場の解析から推定し, その期間について藻類の 増殖解析を行うことによって, 実際の砂河川での藻 類繁茂量・藻類分布が予測できることが期待される。 本研究では, 一般曲線座標系による非定常2次元流 れ場の解析 ${ }^{7} に$, 付着藻類動態を組み込んだモデル を構築した。本解析のフローチャートを図-5に示す。 まず，観測対象河川の流量, 地形データを用いた 浅水流方程式の数值解析を行い, 河床せん断力の平 面分布を算出する. 一方, 現地河川での河床砂に対 してから, 岩垣式より限界掃流力を求めた。もし, 河床のせん断力が限界掃流力より大きい場合は, 河 床の砂が移動状態と判断されるため, その場所の藻 類量を 0 とし, 逆に, 河床せん断力が限界掃流力以 下の場合は, 以下に示すロジスティック方程式によ り, 藻類の増殖解析を行う。

\section{（2）藻類の増殖解析}

藻類の増殖は以下のロジスティック方程式に従う ものとする :

$$
\frac{d M}{d t}=\mu M\left(1-\frac{M}{K}\right)
$$

ここに, $\mu$ : 比増殖速度 $\left(\mathrm{day}^{-1}\right), K$ : 環境容量 $\left(\mathrm{mg} / \mathrm{m}^{2}\right), M$ : 付着藻類の現存量 $\left(\mathrm{mg} / \mathrm{m}^{2}\right)$ であ る.ここで比増殖速度, 環境容量について, 藻類増 殖に関わる環境因子との相関関係を検討する。まず, 比増殖速度は光合成による一次生産力を表すもので あり, 光合成活性と同様に, 水温, 日射, 栄養塩濃 度の影響を受けるものと考えられる. 環境容量につ いては, 付着藻類の増殖可能な最大量を示すもので あり, 基本的には日射量に依存しているものと判断 される. 以上の考察に基づいて, 比増殖速度と環境 容量については以下の関数で表されるものとした.

$$
\begin{gathered}
\mu=\mu_{\max } \cdot f_{T}(T) \cdot f_{I}\left(I_{b}\right) \cdot f_{N}(N) \\
K=K_{\max } \cdot g_{I}\left(I_{b 0}\right)
\end{gathered}
$$

ここに, $f_{T}, f_{I}, f_{N}$ : 比増殖速度に関する水温,
河床日射量, 栄養塩濃度の影響関数, $g_{I}$ : 環境容 量に関する晴天時河床面日射量の影響関数, $T$ : 水 温 $\left({ }^{\circ} \mathrm{C}\right), I_{b}$ : 日平均河床面日射量 $\left(\mathrm{MJm}^{-2} \mathrm{day}^{-1}\right)$, $N$ : 栄養塩濃度 $(\mathrm{mg}), I_{b 0}$ : 晴天時日平均河床面日 射量 $\left(\mathrm{MJm}^{-2} \mathrm{day}^{-1}\right)$ である. $f, g$ といった影響関数はそ れぞれ0〜1の值を取るものとする．それぞれの影響 関数については, 以下の式で与えた.

\section{a) 水温に関する影響関数}

付着藻類の光合成に対する最適水温を中心とした 正規分布型の関数で表されるものとして，以下の式 で表すこととする.

$$
f_{T}(T)=\exp \left[\alpha_{T} \frac{\left(T-T_{o p t}\right)^{2}}{\left(T_{C}-T_{o p t}\right)^{2}}\right]
$$

ここに, $T_{o p t}$ : 光合成の最適水温 $\left({ }^{\circ} \mathrm{C}\right), \alpha_{T}, T_{c}$ : 光合 成速度の水温依存性に関するパラメータ $\left(\alpha_{T}\right.$ : 無次 元， $\left.T_{c}:{ }^{\circ} \mathrm{C}\right)$ である. 光合成の最適水温に関しては, 矢作川中流域における付着藻類の光合成活性に関す る野崎 $ら^{8)}$ の研究成果から最適水温を $T_{o p t}=18\left({ }^{\circ} \mathrm{C}\right)$ と 設定した。 $\alpha_{T}, T_{c}$ に関しては池田ら ${ }^{9}$ による藻類一 次生産速度の解析事例を参考に $\alpha_{T}=-2.3, T c=3\left({ }^{\circ} \mathrm{C}\right)$ と 設定した。

\section{b) 日射量に関する影響関数}

最大比増殖速度,最大環境容量に関寸る影響関数 として日射依存関数を以下の式で算定する.

$$
\begin{aligned}
& f_{I}\left(I_{b}\right)=\frac{I_{b}}{I_{c}+I_{b}} \\
& g_{I}\left(I_{b 0}\right)=\frac{I_{b 0}}{I_{c}+I_{b 0}}
\end{aligned}
$$

ここに， $I_{c}$ ：日射に関する半飽和定数で，田代 ${ }^{10)}$ に 基づいて $I_{c}=5\left(\mathrm{MJm}^{-2} \mathrm{day}^{-1}\right)$ とした.

\section{c）栄養塩に関する影響関数}

ここでの栄養塩はリンを対象とし解析を実施する こととし，以下の式(7)で表すことが出来る．また， このときの $N_{c}$ に関しては野崎ら ${ }^{8)}$ により $N_{c}=0.01 \mathrm{mg} / \mathrm{l}$ とした.

$$
f_{N}(N)=\frac{N}{N_{c}+N}
$$

\section{d）最大比増殖速度と最大環境容量の推定}

式(2)から式(7)を用いて3回の増殖実験時の $\mu_{\text {max }}$, $K_{\max }$ を算出し, その平均值 $\mu_{\max }=0.99 \mathrm{day}^{-1}, K_{\max }=$ $48.6 \mathrm{mg} / \mathrm{m}^{2}$ を以降の解析に用いる.

\section{(3) 計算条件}

計算対象区間は矢作川 $17 \mathrm{~km}$ 地点のリーチ $(16.8 \mathrm{~km} \sim$ 17.6km)である。初期地形としては，国土交通省が 2000年に横断地形測量を 200m間隔で行った地形 データとそれを補間するように現地測量したデータ より作成した。計算格子は流下方向グリッド数が 20 , 横断方向グリッド数は22 とした.またManningの粗 


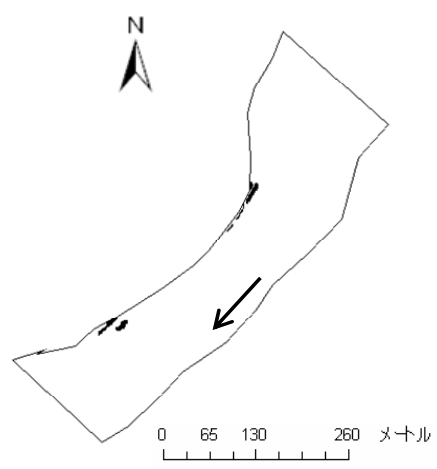

(1) 10 月 30 日

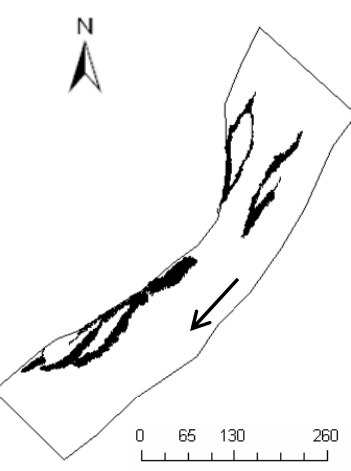

(2) 11月16日

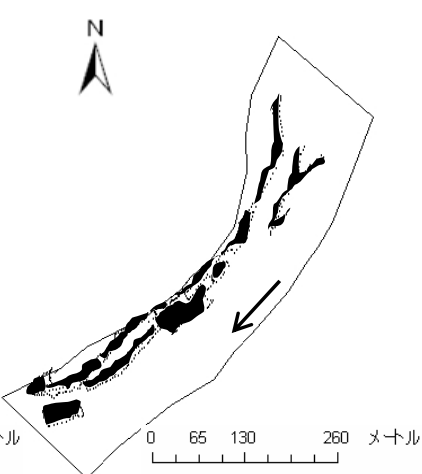

(3) 12 月 12 日

(a) 現地観測結果

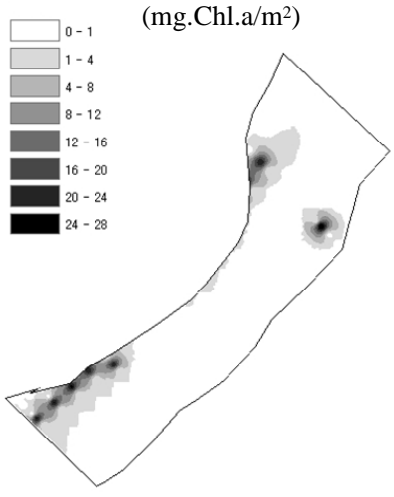

(1) 10月 30 日

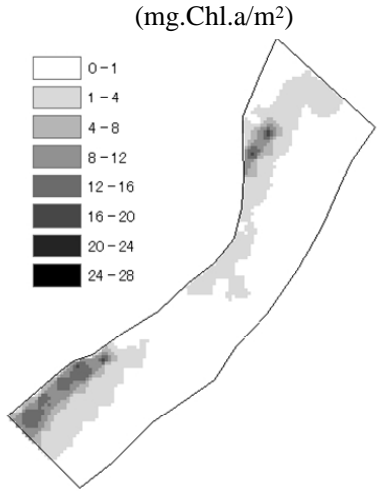

(2) 11月 16 日

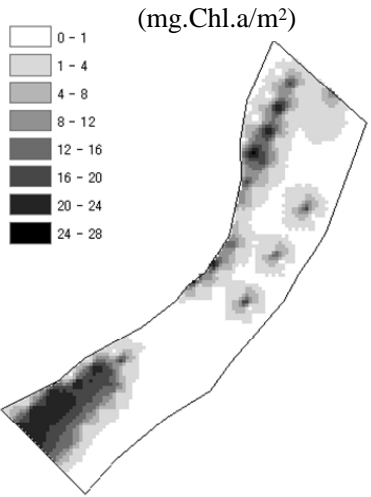

(3) 12 月 12 日

(b) 数值解析結果

図-6 河床付着藻類の分布

度係数を 0.032 とした。計算区間平均での河床勾配 は約1/1500である。 また，河床材料の平均粒径は繁 茂域と非繁茂域には差異がないと確認されたので, 図-3の粒度分布から対象区間で一様に $d_{50}=1.0 \mathrm{~mm}$ と 与えた。水位に関しては, 下流 $4 \mathrm{~km}$ に位置する木戸 観測所と上流 $7.5 \mathrm{~km}$ に位置する岡崎観測所における 水位データから，計算対象区間の下流端である 16.8 $\mathrm{km}$ 地点での水位より算出した。この際, 木津観測所 から岡崎観測所までの水位が線形的に変化するとし て，16.8km地点の水位を算出している。 また, 流量 はH-Q式 $\left(H[\mathrm{~m}+\mathrm{T} . P],. Q\left[\mathrm{~m}^{3} / \mathrm{s}\right]\right)$ を用いて木戸観測所で の流量を算出した。対象区間と木戸観測所の間には 支川の流入はなく，観測所の流量はほぼ対象区間の 流量と等しいものと判断される.

水温, 栄養塩濃度については国土交通省管理の水 文水質データベースから計算対象区域(17km地点)に 最も近い観測所である米津水質自動観測所(10km地 点)のデータを取得し，使用した。また日照時間に ついては気象庁電子閲覧室から, 対象地に一番近い 岡崎地域気象観測所のデータを取得し, 使用した。

前述のとおり矢作川下流域は，明治用水の取水に よる影響で流量, 水深の低下, 河床材料の移動頻度 の低下が生じているものと考えられる。そこで仮に
取水量を制限したケースを想定して，9～12月の4ケ 月間での付着藻類生産量を計算した。流量以外の条 件は一定に保ったままで, 現況流量から $5 \mathrm{~m}^{3} / \mathrm{s}$, $15 \mathrm{~m}^{3} / \mathrm{s}, 20 \mathrm{~m}^{3} / \mathrm{s}, 30 \mathrm{~m}^{3} / \mathrm{s}$ ずつ流量を増加させた $4 つ の$ 場合について計算した，解析方法については前節ま でで用いた手法と同一のものである.

\section{(4) 現地観測の結果と計算結果の比較}

現地観測により得られた付着藻類の繁茂状況と, 計算による付着藻類の空間分布の比較を図-6に示す. 現地観測結果と計算結果を比較すると，どちらも水 深の低い右岸部分に藻類の繁茂域が集中しているこ とがわかる。また三回の現地観測結果から，観測対 象地では，10月中旬の出水後から安定した流量の期 間が続いたため，藻類繁茂域が拡大していることが 分かる。計算結果においてもその拡大の様子は再現 されている。しかし，計算で予測される藻類繁茂域 は現地観測での繁茂域より広く予測されており，ま た，現地観測で見られるような繁茂域の複雑な形状 を再現出来ていないことが分かる。これは，計算格 子や入力地形の解像度の問題等が考えられ, 今後の 課題ではあるものの，単純なアルゴリズムによる本 解析によって砂河川の藻類繁茂の大局的な特徵は再 現できるものと判断される. 


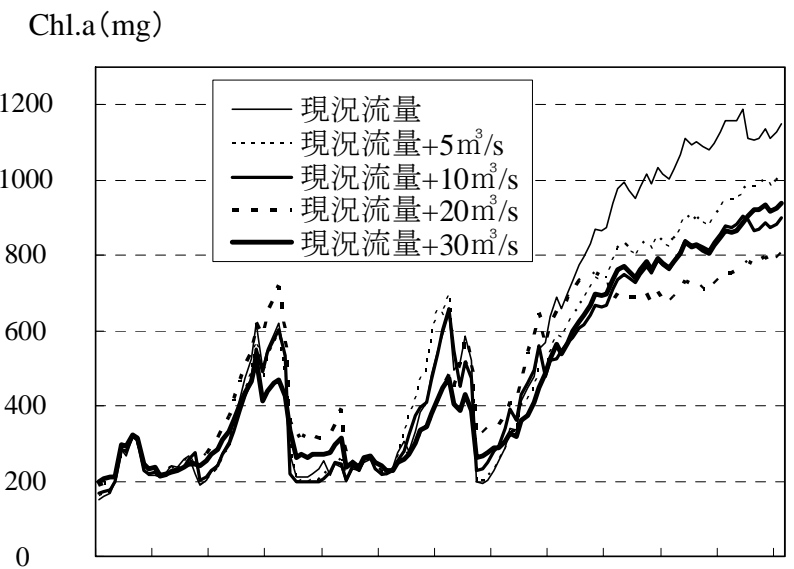

(39)

図-7 対象区間全域における付着藻類量の推移

Chl.a $\left(\mathrm{mg} / \mathrm{m}^{2}\right)$

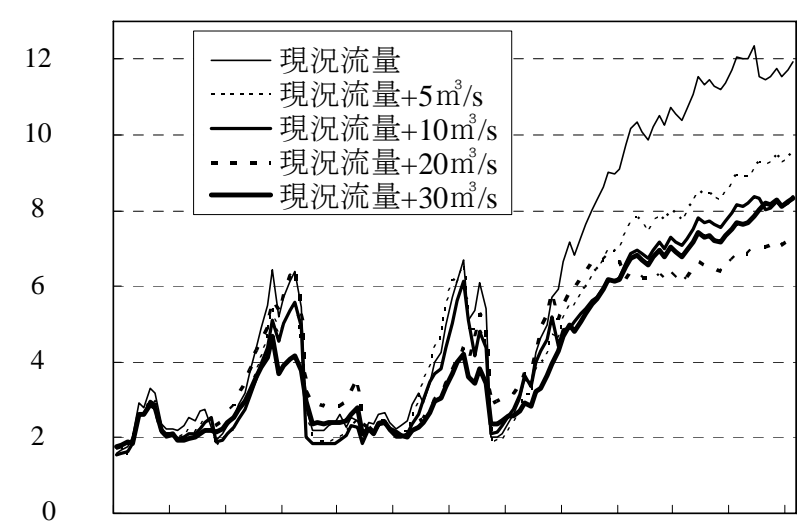

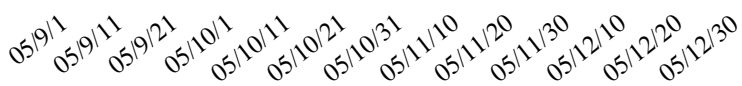

図-8 単位面積当たりの付着藻類量の推移

\section{(5) 流量を変化させた場合の付着藻類量}

現況流量から流量を増加させて計算した場合の対 象区間全域での藻類の生産量を図-7に示した。また 全藻類量を平均流路面積で除した単位面積当たりの 藻類量を図-8に示した。この流路面積は, 計算した 4ケ月間の各流量での平均流量について, 河道内の 冠水部分の面積を算出したものである. 図-7の全区 間での藻類総量については, 現況流量から流量を増 加させても, 単純に藻類量が減る訳ではないものの, 11月中旬から始まる流量安定期の大規模な増殖は字 若干抑制されることが分かる. 図-8より, 単位面積 当たりの藻類量については, 現況流量から流量を増 加させることによって減少寸る傾向にあることが分 かる。これらのことから, 全期間を通じて流量を単 純に一定量増加させると, それぞれの平均的な流量 に対応して低水深の水際部分が形成され，そこで付 着藻類の繁茂が生じるため, 河道全体での藻類量は 流量の単純増加ではあまり変化しないが，流量が大 きい場合には澪筋等の藻類が繁茂していない領域が 水域面積の中で相対的に増えるため, それを平均し
た河床単位面積あたりの藻類量は低下寸ることが分 かる. 逆に河川全域での藻類量を効率的に減らそう とする場合には，一定の期間，安定して低水深であ るような場所を作らないよう，流量変動を大きくす ることが有効であるものと思われる.

\section{4. 結論}

本研究より得られた主たる結論を以下に述べる.

1) 砂河川における付着藻類の繁茂量については, 川岸付近や低水深部分で大きくなる傾向があり, 水深, 掃流力の水理特性と関係している.

2) 砂河川における藻類空間分布予測モデルを提案 した．本モデルにより付着藻類分布を予測した 結果と現地観測により得られた付着藻類の空間 分布とを比較したところ, 概ね一致した.

3）流量を変化させた場合の計算結果から, 効率的 に付着藻類を減少させる場合には, 出水時に 限って現況流量から一定量を増加させると有効 であると考えられる。

\section{参考文献}

1) 戸田祐嗣, 辻本哲郎, 池田拓朗, 多田隈由紀 : 砂河川 における付着藻類の繁茂とそれによる水質変化，河川 技術論文集，第12巻，pp.25-30， 2006.

2) SCOR/UNESCO: Determination of photosynthetic pigments in sea water, Monograph of Oceanographic Methodology,1,1-65, 1975.

3）池田駿介, 戸田祐嗣, 赤松良久: 瀬と淵の水質および 生物一次生産に関する現地観測，水工学論文集，第43 巻, pp.1037-1042, 1999.

4）戸田祐嗣，赤松良久, 池田駿介: 水理特性が付着藻類 の一次生産特性に与える影響に関寸る研究, 土木学会 論文集, Vol.705, pp.161-174, 2002.

5) Stevenson, R. J., Bothwell, M. L., and Lowe, R. L.: Algal ecology -5. Effects of light -, Academic Press, pp.121-148, 1996.

6) 国立天文台編 : 理科年表, 丸善, 1997.

7) 長田信寿 : 一般座標による河川流の計算, 水理公式集 例題プログラム集，例題2-8, 2001.

8）野崎健太郎, 神松幸弘, 山本敏哉, 後藤直成, 三田村 緒佐武: 矢作川中流域における系状藻類Cladophora glomerataの光合成活性, 矢作川研究No.7, pp.169-176, 2003.

9）池田駿介, 戸田祐嗣, 佐野貴之 : 現地観測に基づく瀬 の水理と生物一次生産に関する研究，土木学会論文集， Vol.593, pp.93-104, 1998.

10) 田代喬 : ダム下流河道における河床の低攪乱化に着目 した水域生態系評価に関する研究, 名古屋大学学位論 文, pp.83-113, 2004.

(2006. 9. 30受付) 